JAMP: Jurnal Adminitrasi dan Manajemen Pendidikan

Volume 1 Nomor 1 Maret 2018, Hal:37-44

Tersedia Online di http://journal2.um.ac.id/index.php/jamp/

ISSN $x x x x-x x x x$ (online)

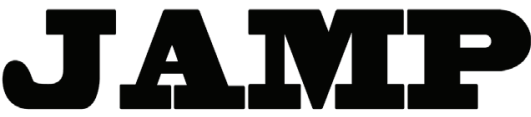

JURNAL ADMINISTRASI DAN MANAJEMEN PENDIDIKAN

\title{
EFEKTIVITAS KEPEMIMPINAN KEPALA SEKOLAH DAN HUBUNGANNYA DENGAN KINERJA GURU
}

\author{
Atikka Ayu Yulisetyawati \\ Burhanuddin \\ Wildan Zulkarnain \\ email: ayuatikka@gmail.com \\ Universitas Negeri Malang, Jl. Semarang No. 5 Malang 65145
}

\begin{abstract}
This study aims to investigate the effectiveness of principal leadership and its relationship with techer performance at Junior High School in Wonokromo Surabaya. This is a quantitative research using a correlational design. Data collection techniques used questionnaires and data were analyzed using descriptive statistic technique. Results shows no significant relationship between principal leadership effectiveness and teacher performance. This indicates that there are other factors may directly affect the teacher performance. Principals need to improve their leadership skills and teachers are expected to improve their performance.
\end{abstract}

Keywords: Leadership Effectiveness, Teacher Performance.

\begin{abstract}
Abstrak: Penelitian ini bertujuan untuk mengetahui efektivitas kepemimpinan kepala sekolah dan hubungannya dengan kinerja guu di SMP se-Kecamatan Wonokromo Kota Surabaya. Penelitian ini merupakan penelitian kuantitatif dengan menggunakan rancangan deskriptif korelasional. Teknik pengumpulan data menggunakan kuesioner dan data yang terkumpul dianalisis dengan teknik descriptive statistic. Hasil penelitian menunjukkan tidak ada hubungan signifikan antara efektivitas kepemimpinan kepala sekolah dan kinerja guru. Hal ini menunjukkan adanya faktor lain yang menetukkan /berpengaruh langsung terhadap aspek kinerja guru. Kepala sekolah perlu meningkatkan kemampuan kepemimpinannya dan para guru diharapkan meningkatkan kinerja.
\end{abstract}

Kata kunci: Efektivitas Kepemimpinan, Kinerja Guru.

Organiasi didirikan sebagai sebagai wadah kerjasama untuk mencapai tujuan tertentu. Pimpinan organisasi harus mampu mengelola berbagai rangkaian kegiatan yang diarahkan pada tujuan yang ingin dicapai.Manusia bertindak sebagai aktor penyelengara organisasi.Agar organisasi tersebut dapat berjalan dengan lancer dan efektif, diperlukan orang-orang yang memiliki kemampuan dengan bidang pekerjaan tertentu.Hal ini menjadi indikator keberhasilan organisasi.

Keberadaan seorang pemimpin sangat penting dalam suatu organisasi, Biasanya pemimpin dijadikan panutan oleh para bawahan atau karyawan untuk melaksanakan pekerjaan, sebagai tempat konsultasi untuk menyelesaikan masalah-masalah lain yang dialami para bawahan atau karyawan di dalam organisasi serta masalah-masalah yang terjadi di tengah-tengah masyarakat.

Kepemimpinan adalah suatu fenomena yang terdapat dalam setiap komunitas, karena dimana manusia berinteraksi maka disana timbul fenomena kepemimpinan, mulai dari interaksi dalam kelompok yang paling primitif sampai ke yang paling maju, mulai dari kelompok yang paling terkecil sampai ke organisasi yang paling besar. Faktor kepemimpinan dalam suatu organisasi menjadi sangat penting 
manakala individu/anggota organisasi memiliki dinamika yang tinggi dalam aktivitasnya disamping perubahan terus-menerus yang didorong oleh kemajuan teknologi.

Menurut Wahjosumidjo (2002) menyebutkan"kepemimpinan kunci keberhasilan sekolah".Kalimat itu berarti bahwa peran kepala sekolah sebagai pemimpin sangat besar terhadap keberhasilan sekolah mencapai tujuan sekolah yang berhasil apabila mereka memahami.Keberadaan sekolah sebagai organisasi yang komplek dan unik, serta mampu melaksanakan peranan kepala sekolah sebagai seorang yang diberi tanggungjawab untuk memimpin sekolah.

Kepemimpinan kepala sekolah mempunyai peran dan pengaruh di dalam kehidupan sekolah, walaupun kepala sekolah bukan merupakan seorang pemimpin yang memiliki kekuasaan mutlak dalam lingkungan kepala sekolah.Sekarang ini sudah banyak sekolah yang oleh pimpinannya diberikan instruksi, bahwa semua unsur dalam suatu lembaga pendidikan adalah pendukung keberhasilan pengelolaan pembelajaran di lembaga pendidikan tersebut.Bagaimana juga kepala sekolah merupakan salah satu kunci penting sukses tidaknya pengelolaan pembelajaran di dalam suatu sekolah.Guru dalam hal ini mempunyai tanggungjawab yang besar terhadap pembentukan pribadi peserta didik, karena guru yang melakukan transfer budaya didalam kelas, dengan begitu guru merupakan contoh teladan bagi peserta didiknya.

Pembelajaran dan perkembangannya merupakan bagian integral dalam bidang manajemen kurikulum dan penerapannya di sekolah saat ini yang semakin banyak ditekuni, terutama oleh para ahli ilmu pendidikan, tenaga professional kependidikan, tenaga peneliti dan para pengelola pendidikan pada berbagai jenjang pendidikan. Kesadaran mengenai pentingnya kemampuan dan keahlian dalam bidang pembelajaran ini sesungguhnya sejalan dengan semakin cepat dan bertambah kompleksnya perkembangan dunia pendidikan, yang merupakan implikasi dan konsekuensi logis dari eksploitasi dalam bidang-bidang ilmu pengetahuan dan teknologi, sosio-kultural, keberhasilan dalam pengendalian penduduk dan anspirasi masyarakat yang dimungkinkan oleh suasana keterbukaan dan komunikasi dua arah secara timbal balik yang berkembang dalam kehidupan bermasyarakat, berbangsa dan bernegara.

Pembelajaran yang berkualitas dapat diwujudkan oleh guru yang mempunyai kualitas dan kompetensi yang tinggi dalam melaksanakan kewajibannya. Jika pembelajaran yang dilakukan guru berkualitas, maka lulusan yang dihasilkan akan berkualitas pula. Sebaliknya, jika pembelajaran yang dilakukan tidak berkualitas, maka lulusan yang dihasilkan juga tidak akan berkualitas. Hal tersebut akan berdampak pada kemampuan lulusan dalam menghadapi persaingan yang semakin ketat di era globalisasi ini, Jadi, dapat dikatakan bahwa keberhasilan pembelajaran bergantung pada kinerja guru.

Kinerja guru dipengaruhi oleh faktor faktor tertentu, seperti yang dikemukakan Barnawi dan Arifin (2012:43)" kinerja guru dipengaruhi oleh faktor internal dan eksternal".Faktor internal kinerja guru adalah faktor yang datang dari dalam diri guru yang dapat mempengaruhi kinerjanya, contohnya ialah gaji, sarana dan prasarana, lingkungan kerja fisik, dan kepemimpinan. Faktor-faktor tersebut akan terus - menerus memengaruhi guru sehingga akan lebih dominan dalam menentukan seberapa baik kinerja guru dalam melaksanakan tugasnya.

Terkait uraian diatas, peneliti mengadakan penelitian di Sekolah Menengah Pertama (SMP) se-Kecamatan Wonokromo kota Surabaya. Penelitian ini bertujuan untuk mengetahui Efektivitas Kepemimpinan, hubungannya terhadap Kinerja. Penelitian ini memberikan inspirasi bagi peneliti untuk mengkaji tentang "Efektivitas Kepemimpinan dan Hubungannya terhadap Kinerja Guru Sekolah Menengah Pertama (SMP) di Kecamatan WonokromoKota Surabaya".

\section{METODE}

Penelitian ini merupakan penelitian kuantitatif, dengan menggunakan teknik deskriptif korelasional. Penelitian deskriptif bertujuan untuk mengetahui mengenai suatu keadaan berupa keadaan apa, bagaimana, berapa banyak, dan sejauh mana keadaan itu. Penelitian deskriptif ini dalam hal ini untuk mendeskripsikan efektivitas kepemimpinan kepala sekolah dan hubungannya dengan kinerja guru di SMP se-Kecamatan Wonokromo Kota Surabaya, langkah berikutnya kedua variabel dikorelasikan. 
Populasi penelitian ini adalah guru Sekolah Menengah Pertama Se-Kecamatan Wonokromo Kota Surabaya. Sekolah Menengah Pertama Se-Kecamatan Wonokromo Kota Surabaya berjumlah 481 guru dari total populasi ini, sampel penelitian sejumlah 214 guru ditetapkan menggunakan teknik random sampling. Peneliti menggunakan angket tertutup karena jenis ini memberikan kemudahan kepada responden untuk menjawab dengan cepat dan memudahkan peneliti dalam melakukan analisis data setelah seluruh angket terkumpul.

Uji coba intrumen penelitian memiliki peran yang sangat penting dalam penelitian kuantitatif karena kualitas data yang diperoleh dalam banyak hal ditentukan oleh kualitas instrumen yang digunakan. Jika instrumen yang digunakan dapat dipertanggungjawabkan, data yang diperoleh juga dapat dipertanggungjawabkan. Peneliti melakukan uji coba penelitian kepada 40 orang responden yang dimiliki karakteristik yang sama dengan calon responden yang diperoleh dari uji coba instrumen selanjutnya peneliti uji dengan persyaratan kualifikasi yang meliputi uji validitas dan uji reliabilitas.

Teknik pengumpulan data yang digunakan dalam penelitian ini adalah teknik angket atau kuesioner. Angket yang digunakan dalam penelitian ini adalah angket tertutup, dimana responden mengisi angket sesuai dengan pilihan jawaban yang sudah disediakan. Teknik analisis data ini menggunakan analisis deskriptif dan analisis korelasi. Untuk uji prasyarat analisis menggunakan uji normalitas, uji linieritas dan uji homogenitas.

\section{HASIL}

\section{Pelaksanaan Tugas Sebagai Tenaga Pendidik}

Data tentang kinerja guru diperoleh melalui angket tertutup dengan 37 butir soal yang diberikan pada guru di SMP se Kecamatan Wonokromo Surabaya.Jumlah responden yang diteliti 214 guru. Berdasarkan hasil analisis deskriptif melalui metode SPSS 16.00 for Windows variabel pelaksanaan tugas sebagai tenaga pendidik (Y) pada guru di SMP se Kecamatan Wokromo Surabaya, menunjukkan bahwa variabel pelaksanaan tugas sebagai tenaga pendidik $(\mathrm{Y})$ memperoleh nilai minimum $=64$ dan maxsimum $=140$.

Berdasarkan perhitungan skor tertinggi 64 dikurangi 140 diperboleh hasil peluang sebesar 76 kemudian dibagi 3, sehingga memperoleh hasil panjang kelas interval sebesar 25. Secara rinci distribusi tingkatan frekuensi dari variabel capaian pelaksanaan tugas sebagai tenaga pendidik dapat dilihat pada tabel 1.

Tabel 4.1 Distribusi Frekuensi Kinerja Guru

\begin{tabular}{ccccc}
\hline No & Interval & Katagori & Frekuensi & Presentase \\
\hline 1 & $>116$ & Tinggi & 41 & $19 \%$ \\
2 & $90-115$ & Sedang & 89 & $4,59 \%$ \\
3 & $64-89$ & Rendah & 84 & $39,25 \%$ \\
\hline & jumlah & & 214 & $100 \%$ \\
\hline
\end{tabular}

Berdasarkan Tabel 1 menunjukan bahwa dari 214 responden, sebanyak 41 responden atau 19\% menyatakan bahwa tingkat capaian pelaksanaan tugas sebagai tenaga pendidik berada pada tingkat tinggi, sebanyak 89 responden atau 4,59\% menyatakan bahwa tingkat pelaksanaan tugas sebagai tenaga pendidik pada tingkat sedang, dan sebanyak 84 responden atau 39,25\% menyatakan bahwa tingkat capaian kinerja guru barada pada tingkat rendah. Berdasarkan paparan data distribusi frekuensi kinerja guru dapat diambil kesimpulan bahwa tingkat variabel pelaksanaan tugas sebagai tenaga pendidik barada pada tingkat "rendah". Berikut diagram distribusi frekuensi capaian pelaksanaan tugas sebagai tenaga pendidik Gambar 1. 


\section{Pelaksanaan Tugas Sebagai Tenaga Pendidik}

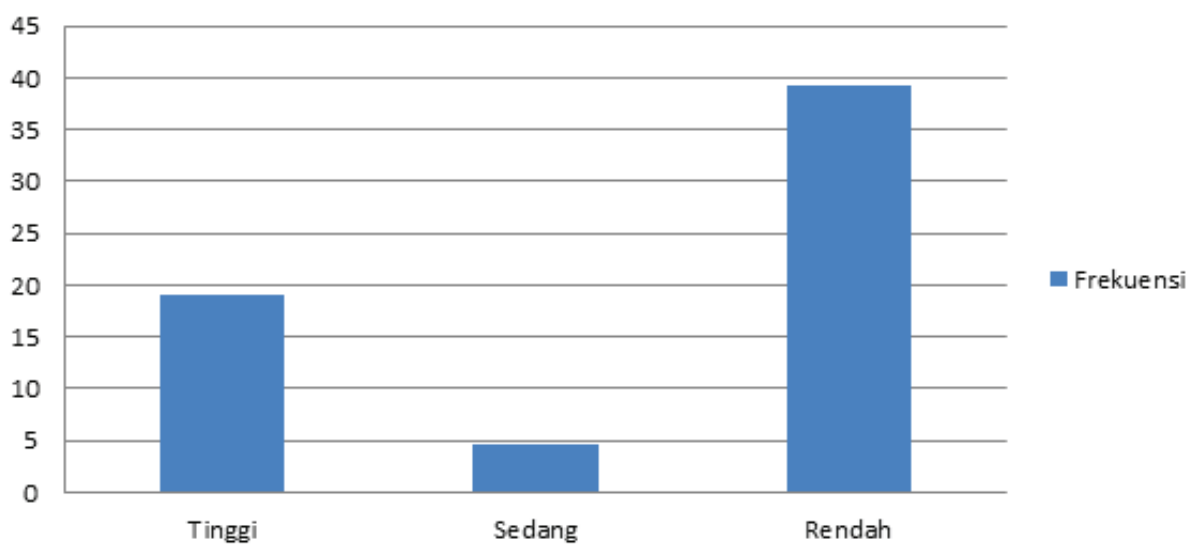

Gambar 1 Diagram Persentase Kinerja Guru

\section{Efektivitas Kepemimpinan}

Efektivitas kepemimpinan diperoleh melalui angket tertutup dengan 19 butir soal yang diberikan pada guru SMP se Kecamatan Wonokromo Surabaya.Jumlah responden yang diteliti sebanyak 214 guru. Berdasarkan hasil analisis deskriptif melalui metode SPSS 16.00 for Windows variabel efektifitas kepemimpinan (X) pada guru SMP se Kecamatan Wonokromo Surabaya, menjukkan bahwa variabel X memperoleh nilai minimum $=19$ dan maximum $=63$. Tingkat efektivitas kepemimpinan yang digunakan pada guru SMP se Kecamatan Wonokromo Surabaya digolongkan menjadi tiga angkatan yaitu, tinggi, sedang dan rendah.Untuk menentukan tingkat tersebut, maka harus diketahui panjang kelas interval dari variabel (X). Berdasarkan perhitungan skor tertinggi 63 dikurangi skor terendah 19 diperoleh hasil peluang sebesar 44 kemudian dibagi 3, sehingga memperoleh hasil panjang kelas interval sebesar 14,6 yang dibulatkan menjadi 15. Secara rici distribusi tingkatan frekuensi efektivitas kepemimpinan dapat dilihat pada tabel 2 .

Tabel 2 Distribusi Frekuensi Efektifitas kepemimpinan

\begin{tabular}{ccccc}
\hline No & Interval & Katagori & Frekuensi & Presentase \\
\hline 1 & $>49$ & Tinggi & 68 & $31,77 \%$ \\
2 & $34-48$ & Sedang & 140 & $65,42 \%$ \\
3 & $19-33$ & Rendah & 6 & $2,8 \%$ \\
\hline & jumlah & & 214 & $99,99 \%$ \\
\hline
\end{tabular}

Berdasarkan tabel 2 menunjukkan bahwa dari 214 responden, sebanyak 68 responden atau 31,77\% menyatakan tingkat efektivitas kepemimpinan berada pada tingkat tinggi, sebanyak 140 responden atau $65,42 \%$ menyatakan bahwa tingkat efektivitas kepemimpinan berada pada tingkat sedang, dan sebanyak 6 responden atau 2,8\% menyatakan bahwa tingkat efektivitas kepemimpinan berada pada tingkat rendah. Berdasarkan paparan data distribusi frekuensi efektivitas kepemimpinan dapat diambil kesimpulan bahwa tingkat efektivitas kepemimimpinan pada guru SMP se Kecamatan Wonokromo Surabaya berada pada tingkat "sedang" sebanyak 140 responden atau $65,42 \%$. Berikut ini akan disajikan uraian dari variabel efektivitas kepemimpinan yaitu gaya kepemimpinan dan tipe-tipe kepemimpinan. Berikut diagram distribusi frekuensi efektivitas kepemimpinan pada Gambar 3. 


\section{Efektivitas Kepemimpinan}

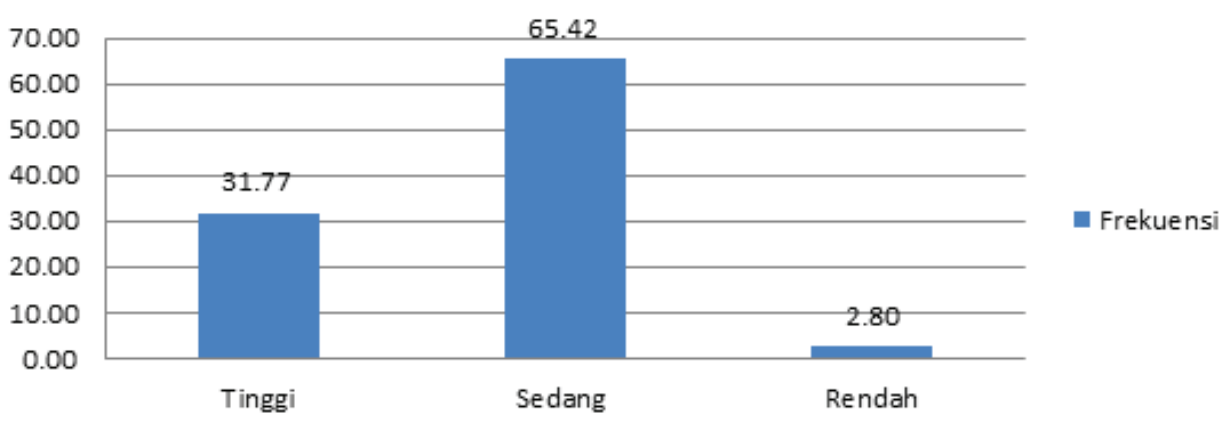

Gambar 4.3 Diagram Presentase variabel Efektivitas kepemimpinan

\section{Analisis Korelasi}

Analisis korelasi yang digunakan adalah analisis Korelasi product moment person, analisis ini digunakan untuk mengetahui ada tidaknya hubungan antara variabel efektivita kepemimpinan $(\mathrm{X})$ dan variabel kinerja guru (Y).

Data yang diperoleh mengunakan teknik analis korelasi product moment pearson menunjukan, bahwa nilai rhitung $=0,080$ yang berarti dalam kategori tidak ada korelasi antara dua variabel dengan signifikansi 2 tailed $=0,243>0,05$ maka dengan demikian kriteria pengujian hipotesis menyatakan H0diterima dan H1ditolak. hal ini menunjukkan tidak ada hubungan signifikan antara efektivitas kepemimpinan dan hubungan kinerja guru. berdasarkan hasil analisis korelasi pada tabel 4.9 dapat dilihat bahwa pearson Correlation memiliki nilai negative sebesar 0,08 yang menandakan adanya arus hubungan yang negative antara efektivitas kepemimpinan dan hubungan kinerja guru dalam kategori tidak ada hubungan.

\section{PEMBAHASAN}

\section{Tingkat Kinerja Guru di SMP se-Kecamatan Wonokromo Kota Surabaya}

Kinerja guru dapat membantu upaya organisasi dalam rangka mengembangkan dan meningkatkan kinerja agar sesuai dengan apa yang di harapkan organisasi. Tujuan kinerja juga perlu penilaian, yaitu untuk mengetahui apakah suatu program pendidikan, pengajaran ataupun pelatihan tersebut telah dikuasai dengan baik atau belum.

Seperti yang dijelaskan dalam Undang-Undang Republik Indonesia Nomor 14 Tahun 2005 tentang Guru dan Dosen (UU RI No. 14/2005), bahwa "guru adalah pendidik profesional dengan tugas utama mendidik, mengajar, membimbing, mengarahkan, melatih, menilai, dan mengevaluasi peserta didik pada pendidikan anak usia dini jalur pendidikan formal, pendidikan dasar, dan pendidikan menengah". Guru dalam menjalankan tugas keprofesionalannya seperti yang terdapat pada Undang-Undang Republik Indonesia Nomor 14 Tahun 2005 tentang Guru dan Dosen UU RI No. 14/2005 berkewajiban untuk:

(1) Merencanakan pembelajaran, melaksanakan proses pembelajaran yang bermutu, serta menilai dan mengevaluasi hasil pembelajaran, (2) Meningkatkan dan mengembangkan kualifikasi akademik dan kompetensi secara berkelanjutan sejalan dengan perkembangan ilmu pengetahuan, teknologi, dan seni, (3) Bertindak objektif dan tidak diskriminatif atas dasar pertimbangan jenis kelamin, agama, suku, ras, dan kondisi fisik tertentu, atau latar belakang keluarga, dan status sosial ekonomi peserta didik dalam pembelajaran, (4) Menjunjung tinggi peraturan perundang-undangan, hukum, dan kode etik guru, serta nilai-nilai agama dan etika, dan (5) Memelihara dan memupuk persatuan dan kesatuan bangsa. 
Berdasarkan hasil penelitian pelaksanakan tugas sebagai tenaga pendidik yang memiliki frekuensi rendah adalah pelaksanakan tugas. Terbukti sebanyak 87 dari 214 atau 40,19\% menyatakan bahwa pelaksanakan tugas pendidik yang dimiki guru di SMP se-Kecamatan Wonokromo Kota Surabaya berada pada tingkat rendah. Hasil penelitian tentang penilaian kinerja guru secara kologial yang diberikan kepada 214 responden bahwa sebanyak 111 responden atau 51,87\% menyatakan bahwa penilaian kinerja guru pendidik yang dimiki guru di SMP se-Kecamatan Wonokromo Kota Surabaya berada pada sedang.

\section{Efektivitas Kepemimpinan di SMP se-Kecamatan Wonokromo Kota Surabaya}

Peningkatan mutu pendidikan nasional dilakukan oleh pemerintah melalui peningkatan kualitas pendidikan disekolah. Keberhasilan pendidikan di sekolah antara lain ditentukan oleh aspek kepemimpinan kepala sekolah sebagai pemimpin lembaga pendidikan. Apabila kepala sekolah dalam melaksanakan fungsi kepemimpinan pendidikan di sekolah, mka pelaksanaan pendidikan diharapkankan berjalan efektif.Dapat dilaksanakan atau tidaknya suatu program pendidikan dan tercapai atau tidaknya tujuan pendidikan, sangat bergantung pada kecakapan dan kebijaksanaan kepala sekolah sebagai pemimpin pendidikan (Purwanto, 1990).

Sedangkan fungsi kepemimpinan pendidikan menunjuk kepada berbagai aktivitas atau tindakan yang di lakukan oleh kepala sekolah dalam upaya menggerakkan guru-guru, karyawan, siswa, dan anggota masyarakat agar mau berbuat sesuatu guna menyukseskan program-program pendidikan di sekolah. Berdasarkan angket penelitian yang telah diisi oleh 214 responden tentang efektivitas kepemimpinan maka hasil penelitian menunjukkan efektivitas kepemimpinan yang ada di SMP se-Kecamatan Wonokromo Surabaya termasuk dalam kategori tingkat sedang. Terbukti sebanyak 140 responden atau $65,42 \%$ menyatakan bahwa efektivitas kepemimpinan sudah cukup baik karena pemimpin atau kepala sekolah telah melakukan tindakan upaya menggerakkan guru, karyawan, siswa agar mau berbuat suatu guna menyukseskan program-program yang ada di sekolah.

Gaya kepemimpinan juga memiliki tingkat frekuensi yang berbeda-beda. Tidak semua unsur gaya kepemimpinan memiliki frekuensi yang tinggi. Terbukti sebanyak 95 responden atau 44,40\% menyatakan bahwa gaya kepemimpinan yang ada di SMP se Kecamatan Wonokromo Kota Surabaya sudah baik karena pemimpin telah melakukan perilakudalam menjalankan kepemimpinannya, mengarahkan bawahan, dan memberi perintah kepada anggotnya agar dapat bergerak sesuai keinginannya dalam rangka mencapai tujuan organisasi.

Tipe-tipe kepemimpinan juga memiliki tingkat frekuensi yang berbeda-beda tidak semua unsur tipe-tipe kepemimpinan memiliki frekuensi yang tinggi. Terbukti sebanyak 160 responden atau 74,8\% menyatakan bahwa tipe-tipe kepemimpinan yang ada di SMP se Kecamatan Wonokromo Kota Surabaya sudah cukup baik karena pemimpin.kepala sekolah sudah mengenai 4 tipe kepemimpinan yaitu: tipe Autiritarian (sifat berkuasa), tipe Laizzer-Faire (pemimpin hanya berfungsi sebagai simbol), tipe Demokratis (pemimpin selalu mengikut sertakan seluruh anggota/bawahan untuk mengambil keputusan), dan tipe Semu Demokratis/Pseudo-demokratis tipe ini pemimpin berpura-pura menggunakan ide anggota/bawahan dalam pengambilan keputusan, padahal dalam kenyataannya pemimpin sendiri yang memutuskan segala sesuatu.

\section{Efektivitas Kepemimpinan dan Hubungannya Terhadap Kinerja Guru di SMP se- Kecamatan Wonokromo Kota Surabaya}

Berdasarkan hasil pungujian hipotesis mengatakan bahwa tidak ada hubungan yang signifikan antara efektivitas kepemimpinan (X) dan hubungan kinerja guru (Y).hal tersebut ditunjukkan dari hasil pengujian korelasi yang dilakukan dengan SPSS for windows 16.00, didapatkan nilai signifikansi 0,000 $<0,05$ dengan hasil korelasi 0,080. Dari hasil korelasi tersebut dapat dinyatakan tidak hubungan yang signifikan, yang berarti bahwa variabel efektivitas kepemimpinan $(\mathrm{X})$ dan hubungan kinerja guru $(\mathrm{Y})$. Hasil penelitian ini sejalan dengan penelitian yang dilakukan oleh Puji Yuli Astutik (2001:67) yang menunjukkan tidak ada hubungan yang signifikan antara kemampuan pendidikan kepala sekolah pria dan kemampuan pendidikan kepala sekolah wanita di SDN di Kota Malang. 
Berdasarkan penjabaran hasil penelitian diatas tidak ada hubungan yang signifikan antara efektivitas kepemimpinan dan hubungan terhadap kinerja guru di SMP se-Kecamatan Wonokromo, dengan nilai signifikansi antara variabel $(\mathrm{X})$ efektivitas kepemimpinan(rhitung $=0,080$ dengan $\mathrm{p}=0,000)$ terdapat variabel (Y) hubungan terhadap kinerja guru, karena nilai probabilitas (signifikan) $<0,05$ yakni 0,000 dan rhitung $(0,243)>\operatorname{rtabel}(0,05)$ maka hipotesis menyatakan $\mathrm{H} 0$ diterima dan $\mathrm{H} 1$ di tolak yakni tidak ada hubungan yang signifikan antara efektivitas kepemimpinan dan kinerja guru.Dengan demikian terbukti secara umum tidak ada hubungan yang signifikan antara efektivitas kepemimpinan dan kinerja guru. Walaupun tidak ada hubungan langsung 2 variabel tersebut menandakan bahwa masih ada faktor-faktor lain yang diduga mempengaruhi secara langsung kepada kinerja guru terutama dalam melaksanakan tugas sebagai pengajar dikelas.

\section{KESIMPULAN DAN SARAN}

\section{Kesimpulan}

Efektivitas kepemimpinan di SMP se-kecamatan Wonokromo Kota Surabaya berada pada tingkat sedang. Hasil tersebut membuktikan bahwa kepemimpinan di sekolah sudah sesuai dengan kemampuan yang dimiliki oleh guru/ pengajar di sekolah.Kinerja guru/Pendidik di SMP se-kecamatan Wonokromo Kota Surabaya berada pada tingkat rendah. Hasil tersebut membuktikan bahwa kinerja guru disekolah perlu ditingkatkan lagi dalam melaksanakan tugas sesuai standart dan kriteria yang ditetapkan oleh pemerintah.Tidak ada hubungan yang signifikan antara efektivitas kepemimpinan dan hubungannya terhadap kinerja guru di SMP se-Kecamatan Wonokromo Kota Surabaya. Karena hipotesis menyatakan H0 diterima dan $\mathrm{H} 1$ ditolak, hal ini menunjukkan tidak adanya hubungan signifikan antara kedua variabel, berdasarkan hasil analisis korelasi pearson correlation memiliki nilai negative sebesar - 0,29 yang menandakan adanya arus hubungan yang negative antara efektivitas kepemimpinan dan hubungan terhadap kinerja guru maka dari itu dapat dikatakan tidak ada hubungan antara kedua variabel tersebut. Hal ini menunjukkan adanya faktor lain yang menetukkan/berpengaruh langsung terhadap aspek kinerja guru. Kepala sekolah perlu meningkatkan kemampuan kepemimpinannya dan para guru diharapkan meningkatkan kinerja.

\section{Saran}

Kepala SMP se-Kecamatan Wonokromo Kota Surabaya hendaknya senantiasa meningkatkan kemampuan kepemimpinannya terutama dalam menguasai beberapa teknik dan pendekatan kepemimpinan secara professional. Guru SMP se-Kecamatan Wonokromo Kota Surabaya Diharapkan meningkatkan kinerja kearah yang lebih baik sesuai dengan kompetensi-kompetensi dan kemampuan yang dimiliki. Ketua Jurusan Administrasi Pendidikan diharapkan memberikan tambahan referensi bagi kajian ilmu. Penelitian ini hendaknya bisa digunakan sebagai acuan dalam penelitian tentang efektivitas kepemimpinan dan hubungannya terhadap kinerja guru, tentunya menggunakan teknik dan instrument yang lebih baik dan sempurna. Penelitian ini memiliki keterbatasan, maka diharapkan penelitian lain untuk melakukan penelitian selajutnya dengan variabel yang berbeda yang memiliki kaitan dengan efektivitas kepemimpinan dan hubungan kinerja guru.

\section{DAFTAR RUJUKAN}

Arikunto. 2006. Prosedur Penelitian : Suatu Pendekatan. Jakarta: Rineka Cipta.

Arikunto, Suharsimi.2010. Prosedur Penelitian : Suatu Pendekatan. Jakarta: Rineka Cipta.

Bernawi\&Arifin, M. 2012. Manajemen Sarana dan Prasarana Sekolah. Jogjakarta : Ar-ruzz Media.

Burhanuddin.1994. Analisis Administrasi Manajemen dan Kepemimpinan Pendidikan. Jakarta: Bumi Aksara.

Burhanuddin. 2016. Perilaku Organisasi dalam Manajemen dan Kepemimpinan. Malang: Universitas Negeri Malang.

Grounlun dan Linn dalam (Wiyono\&Sunarni). 2009. Evaluasi Program Pendidikan dan Pembelajaran. Malang: Universitas Negeri Malang. 
Depdiknas. 2004. Peraturan Depertemen Pendidikan Nasional..

Undang-Undang Republik Indonesia Nomor 20 Tahun 2003 Tentang Sistem Pendidikan Nasional

Mangkunegara. 2006. Evaluasi Kinerja Sumber Daya Manusia. Jakarta:Refika Aditama.

Margono. 2007. Metodologi Penelitian Pendidikan: Jakarta: Rineka Cipta.

Peraturan Menteri Pendidikan Nasional Nomor 13 Tahun 2007 Tentang Standar Kepala Sekolah.

Siregar, S. 2013. Metodelogi Penelitian Kuantitatif : Dilengkapi Dengan Perbandingan Manual\&SPSS. Jakarta:Kencana.

Sudrajad, Akhmad. Penelitian Tindakan Kelas Part II dalam (http://akhmadsudrajad.word press.com/2008/03/21/ penelitian-tindakan-kelas-part-ii/diakses tanggal 3 Februari 2016.

Setyadin, B. 2005. Desain dan Modul Penelitian Kuantitatif. Malang: Universitas Negeri Malang.

Sugiono. 2011. Metode Penelitian Kuantitatif, Kualitatif dan R\&D: Alfabeta.

Soetopo, Hendyat. 2010. Perilaku Organiusasi. Jakarta: PT.Remaja Rosdakarya.

Soetopo, Hendyat. 2010. Kepemimpinan pendidikan. Malang: FIP UM.

Suparlan. 2005. Menjadi Guru Efektiv. Yogyakarta: Hikayat Publising.

Universitas Negeri Malang .2010. Pedoman Penulisan Karya Ilmiah. Malang: Universitas Negeri Malang.

Undang-Undang Republik Indonesia Nomer 14 Tahun 2015. Tentang Guru dan dosen (UU RI N0.14/2015)

Wahap dan Umiarso. 2011. Kepemimpinan Pendidilkan dan Kecerdasan Spiritual. Jogjakarta : Ar-Ruzz.

Wiyono, Bambang, Budi.2008. Metode Penelitian: Pendekatan Kuantitatif, Kualitatif dan Action Research(Burhanuddin.Ed). Malang: Universitas Negeri Malang.

Yamin, M. 2010. Standart dan penelitian Kinerja Guru. Jakarta:Gaung Prasada.

Zulkarnain, Wildan. 2013. Dinamika Kelompok: Latihan Kepemimpinan Pendidikan. Jakarta: Bumi Aksara. 